Joanna Schubel

\title{
Gestaltungsfreiheit und Gestaltungsgrenzen im polnischen Vertragskonzernrecht
}

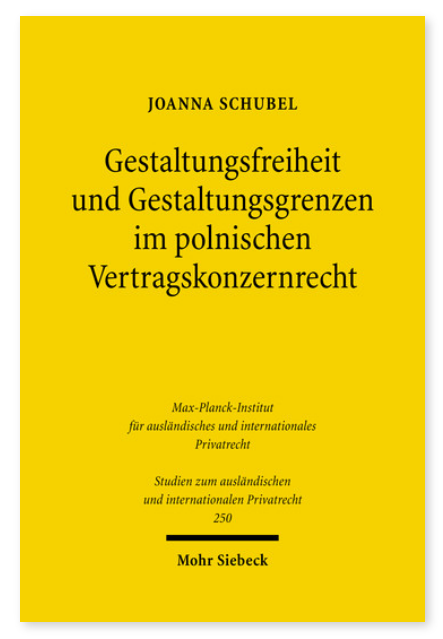

2010. XXV, 567 Seiten. StudIPR 250

ISBN 978-3-16-151435-7

DOI 10.1628/978-3-16-151435-7

eBook PDF 114,00€

ISBN 978-3-16-150243-9

fadengeheftete Broschur 114,00€
Der Beitritt zur Europäischen Gemeinschaft hat in den ostmitteleuropäischen Staaten Reformen des Gesellschaftsrechts veranlasst, welche teilweise auch die Schaffung eines modernen Konzernrechts beinhalten. Joanna Schubel untersucht die konzernrechtlichen Regelungen des polnischen Gesetzbuches für Handelsgesellschaften (KSH) aus dem Jahre 2000 und des ungarischen Konzernrechts von 2006. Sie zeigt den Beteiligten nationaler und grenzüberschreitender Unternehmensgruppen Wege auf, ihre Beziehungen unter Berücksichtigung unterschiedlicher Gruppenstrategien rechtssicher zu gestalten. Hierfür ist nach Ansicht der Autorin der Abschluss von Konzernverträgen zu empfehlen, für deren Ausgestaltung sie der Praxis Gestaltungsvorschläge unterbreitet. Der Blick auf das polnische und ungarische Recht demonstriert zugleich, wie das deutsche Vertragskonzernrecht weiterentwickelt werden könnte.

Joanna Schubel Geboren 1979; Studium der Rechtswissenschaft in Krakau und Heidelberg; 2004-07 Graduiertenkolleg an der Andrássy Universität Budapest; 2009 Promotion; Associate in der Rechtanwaltskanzlei DZP in Warschau.
Jetzt bestellen:

https://mohrsiebeck.com/buch/gestaltungsfreiheit-und-gestaltungsgrenzen-im-polnischen-vertragskonzernrecht-

9783161514357?no_cache=1

order@mohrsiebeck.com

Telefon: +49 (0)7071-923-17

Telefax: +49 (0)7071-51104 